\title{
DEVELOPING A STRATEGIC SUSTAINABLE FACILITY PLAN FOR A HOSPITAL LAYOUT USING ELECTRE AND APPLES PROCEDURE
}

\author{
Vimal K.E.K ${ }^{1}$, Jayakrishna KANDASAMY ${ }^{2}$, Simon Peter NADEEM ${ }^{3}$, Anil KUMAR ${ }^{4, *}$, \\ Jonas ŠAPARAUSKAS ${ }^{5}$, Jose Arturo GARZA-REYES ${ }^{3}$, Eva TRINKŪNIENE் ${ }^{6}$ \\ ${ }^{1}$ Department of Mechanical Engineering, National Institute of Technology, Patna, Bihar, India \\ ${ }^{2}$ School of Mechanical Engineering, VIT University, Vellore, Tamil Nadu, India \\ ${ }^{3}$ Centre for Supply Chain Improvement, University of Derby, Derby, United Kingdom \\ ${ }^{4}$ Guildhall School of Business and Law, London Metropolitan University, London, United Kingdom \\ ${ }^{5}$ Department of Construction Management and Real Estate, Vilnius Gediminas Technical University, Vilnius, Lithuania \\ ${ }^{6}$ Department of Law, Faculty of Business Management, Vilnius Gediminas Technical University, Vilnius, Lithuania
}

Received 30 April 2020; accepted 20 August 2020

\begin{abstract}
Today healthcare globally is growing at a rapid pace and despite the huge technological advancement, healthcare still faces primitive challenges and hence results in the poor service and facility to the needy. Layout planning acts as one major reason which requires improvements for the effective and efficient working of the healthcare facilities. This research aims at optimizing several quantitative criteria related to economic, technology and society which are taken into consideration for the decision-making during the evaluation, analysing and selection of the best layout for an existing healthcare facility. Critical areas for the improvement were found out using statistical analysis based on a survey questionnaire and Apple's layout procedure is utilised to design the different possible layouts for an efficient facility. The seven criteria namely inter-departmental satisfactory level, the average distance travelled and the average time required for staff flow, the average distance travelled and the average time required for patient flow, the average distance travelled and the average time required for material flow were taken into consideration. The ELECTRE methodology was used as multi-criteria decision making based on decided seven criteria for comparing the different layout by methodical and orderly thinking.
\end{abstract}

Keywords: healthcare facility, layout planning, statistical analysis, Apple’s layout procedure, ELECTRE, outranking.

\section{Introduction}

Healthcare in India is growing at a rapid pace of $18 \%$ compound annual growth rate and is one of the fastestgrowing sectors at present yet there is a lot of misbalance within the healthcare infrastructure (IBEF Report, 2020). Most of the hospitals are being developed by private firms and Multi-National Companies, yet the infrastructure is not able to deliver their services to various segments and results in poor performance both economically and socially, facility planning not only help build an effective infrastructure but also help cater to the Indian population of all types and with an economic benefit over time. Facility planning is now being considered in the healthcare facility perspective. There is an increasing demand for better healthcare assistance and facilities (Che-Ani \& Ali, 2019). Primary components on which any facility planning relies are design layout, accommodation of people, processes and activities within the facility (Dwijayanti et al., 2010). The domain brings in new challenges and difficulties yet the end goal is to reduce the cost and increase the efficiency of the facility, hence designing optimized healthcare facility (Chen \& Sha, 2001). When it comes to facilities layout planning for any organization (Manufacturing industry, Production units, Healthcare units, etc.), multifloor facilities planning plays a crucial role in optimizing various parameters. The major success factors for any healthcare facilities construction are based on eight general groups mainly scope, environmental, time, external matter, cost, risk, quality and human resource (Doulabi \& Asnaashari, 2016). Multi-floor layout planning also focuses on decision making aspects like department allocation on floors, the requirement of elevators, the exact location of elevators in the layout, start and end point for material handling (Ahmadi et al., 2017). Proper planning of facilities leads to cost reduction and increases in the overall

*Corresponding author. E-mail: anilror@gmail.com 
efficiency (Riedel, 2011). Other than industrial environment facilities planning also has applications in schools, hospitals and airports planning (Helber et al., 2016).

This research utilises a statistical approach to understand the operational difficulties based on the opinions of stakeholders. The results of the statistical analysis provide quantitative data for better decision making. Apple's layout procedure considers the basic parameters related to the facility layout. It observes the productive processes, material flow patterns and material handling at the facility. Different operations and activity inter-relationships are the major parameters considered for data processing. For the multi-floor layout planning, the departmental swap between the floors is also possible using this procedure while considering the required criteria. The proposed layout is evaluated, adjusted, and rechecked by the experts and the approval for the modifications is obtained from the respective representatives (Lather et al., 2020).

Case study for layout planning of healthcare facility situated in Vellore (India) involves an analysis based on multiple criteria for decision making. In several decisionmaking problems considering multiple criteria, ELECTRE is proved to be effective for ranking purpose (Mary \& Suganya, 2016). The concept of outranking relations used in the ELECTRE method alone can identify the choice between two different alternatives (Girubha et al., 2016). ELECTRE is used as a multicriteria decision-making method based on outranking approach consisting of both quantitative and qualitative criteria (Agrebi et al., 2017). As the existing healthcare facility considered for analysis lacks in proper layout planning, this research aims to optimize the current layout by combining different techniques available with the in-depth involvement and consultation from the medical professionals, engineers, and stakeholders. The current layout is to be improved for efficient and effective flows and operations. To provide a more practical and reliable solution to the stakeholders of the facility, this research uses the ELECTRE method as it is one of the most effective and efficient for MCDA (Multi-Criteria Decision Analysis) in decision-making problems, giving the flexibility on the development of planning with a calculated approach. The research examines the current shortcomings in the layout of a healthcare facility in Vellore, India. The survey questionnaire was developed in consultation with experts in the field of healthcare facility planning. Survey results and their statistical analysis identified critical departments. Apple's layout procedure with the help of a manually generated space-filling curve is used for the design of possible alternative layouts. The decision matrix is obtained containing values calculated for every criterion for each layout in a methodical manner. The ELECTRE method is used for prioritizing the layouts by comparing every pair of layouts by outranking approach and obtain the best layout.

The rest of the paper is structured in a total of $5 \mathrm{sec}-$ tions with section 2 presents the research methodology adopted for this research in section 3. Section 3 presents the case study, analysis and results obtained, section 4 pre- sents the ELECTRE method calculations, section 5 presents the results and discussion and finally, the last section concludes the paper.

\section{Literature review}

The literature has been reviewed to understand the concept of facility planning in the health care sector and the application of ELECTRE in decision-making problems.

\subsection{Review on facility planning in the health care sector}

Facility planning impacts the operational and business efficiency of the healthcare sector (Tongur et al., 2019). Various parameters such as inbound patient room facility directly impact the safety in terms of hygiene and accessibility of the room to other departments (Joseph \& Rashid, 2007). There have been very few incidents wherein the healthcare providers made a mistake due to the planning, yet the essence of the service that is being provided to the patients in hardly been taken care of. This results in the development of a system-centred facility rather than using patient behaviour as one of the topics (Palatnik, 2016; Holden, 2009). The ultimate result of the system centred approach for hospital planning results in the expensive outcome but the results is not in place for the patient's satisfaction (Gonzalez, 2019; Reason, 2000).

Shohet and Lavy (2017) investigated healthcare facility management in the Israeli health care system. The study reveals that the facility management and maintenance have a potential influence on the overall improved performance of healthcare facility services. Yousefli et al. (2017) conducted a literature survey to examine the role of information technology and decision-making support system in maintaining the hospital facility. The study reveals that the literature in hospital management is minimal and needs extensive studies. Mills et al. (2015) conducted an empirical study to examine the relationship between building age and yearly critical backlog. The study reveals the need for considering building backlog in strategic assets management. Further, the need for extensive study in building age and conditional maintenance were highlighted. Amankwah et al. (2019) questionnaire survey using to evaluate the influence of facility management quality on patient satisfaction. The results of the study revealed that the facility management service has an impact on satisfaction, which is due to improved quality of delivery, health care personal, and availability of resources.

Reijula et al. (2016) attempt to examine the challenges and insights associated with the health care facility design in two public-funded hospitals. The hospitals under study carried out a rigorous renovation by implementing some lean ideas with a focus to improve the aesthetics and other facilities. Based on the study, it is found that facility design should focus on improving communication and movement between stakeholder of health care facility. Schaumann et al. (2020) conducted a simulation- 
based study to explore the potential impact of dayroom which can reduce the visitor's density in corridors. The simulation results show that the presence of dayroom can minimize the staff - visitor interaction which can improve operational efficiency. Prugsiganont and Jensen (2018) assessed the functional quality of the unused area in the public hospital to manage the space constrain the problem. The study reveals that lack of strategic space planning and integration was the major reason for poor accessibility and lower flexibility.

Operating certain area within the facility might look not be that important but when considering a few critical areas such as operating room wherein the operating cost may increase due to low efficiency within the hospital and can result in the economic loss for the hospitals (Krupka \& Sandberg, 2006; Palmer et al., 2013). Therefore, improving the critical areas will increase their accessibility and smooth flow can result in better operational efficiency, cost-saving with low-risk rate and higher profits. These potential outcomes highlight/emphasise the need for planning the healthcare facility, a crucial role in the development of the hospitals. There have been various cases where after the construction is complete, the problems start to surface when the actual interactions of the patients, staff and the doctors take place (Wanigarathna et al., 2019), leading to lower efficiency and negative impact on the staff and patients. Numerous techniques are utilised for planning of the healthcare facility through statistical analysis, experienced-based interpretations, and full-scale mock-up designs.

Assigning departments to different floors is done in a two-stage process to reduce the cost for material handling between the floors (Meller \& Bozer, 1997). In the first stage, departments are assigned permanently to one of the floors (using the quadratic model) and in the second stage, the SABLE process is modified and run for placing departments that are not fixed and improving the layouts for efficient material handling and cost reduction. Meller and Bozer (1997) highlights the importance of the twostage approach to solve a layout problem as the research from 1986 to 1996 had diverging results. Moreover, the researchers noted that the assumptions made before planning the layouts were sometimes not appropriate (Meller \& Gau, 1996). The extension of CRAFT algorithm using space-filling curves is a versatile tool to solve the facility layout problems (Heragu, 2016), both for a single and multi-floor facility. This is done to simplify the exchange between any two departments making sure the exchanges are powerful enough to give good results. MULTIPLE is the best suitable improvement type algorithm that overshadows CRAFT in facility planning for both single and multi-floor by its ability to use space-filling curves and handling a various range of area requirements for different departments, ultimately giving cost-efficient outputs (Bozer et al., 1994). Another tool, ALDEP is not suitable for multi-floor layout planning.

Ant colony optimization (ACO) is a metaheuristic algorithm to solve facility layout problems (Liu \& Liu,
2019). The algorithm uses a slicing tree representation (Komarudin \& Wong, 2010) and can be used for several departments ranging from 7 to 62 . A modified version of it was utilised for facilities planning problem in one of the districts of Malaysia. Various objective functions have been used to solve different problems which later are optimized using various other approaches (Shariff et al., 2012). When it comes to facilities planning for any organization, types of layouts (Fixed product, Process, Product, Cellular) are of utmost importance. Due to the limited availability of software tools in manufacturing design, the approach needs to be proper for solving any facility layout problem (Amine et al., 2007). Apple's layout procedure is also an effective facility layout planning tool which considers primary parameters related to the facility layout. It focuses on coordination of departments in a particular flow and analyzes the interdepartmental satisfaction level, which in result gave the best-suited layout output (Benitez et al., 2019). This procedure can also be applied to a multi-floor plan with the manually generated space-filling curve. Roy (1991) utilises the outranking approach and outranking relation concept to solve the real-life problem.

\subsection{Application of ELECTRE method in decision- making}

The basic theory and concept for building such outranking relations and different types of ELECTRE method are explained with some practical considerations. ELECTRE III is as an efficient and effective technique, methodical and orderly thinking, and guides in making logical and robust decisions. ELECTRE III can be used for problems in the management domain of civil engineering as well as in other disciplines (Ulubeyli \& Kazaz, 2009).

A wind farm in NE Poland (Łaska, 2017) uses six different types of multi-criteria decision-making techniques namely MAUT, AHP, and DEMATEL for utility functions, ELECTRE and PROMETHEE and Relationships Outranking are used for the decision support to choose the location. ELECTRE method is used for the prioritization of a web-based decision support model. The inputs required for the proposed system are taken from the different stakeholders by using the 100-point method. Cost of implementation and man-hours needed for the implementation is reduced in a developed system which was validated using a pilot project. Different weights can cause bias in the ranking, as weighting for stakeholders is given by the owner. Generally, a collected dataset can be used in the future for giving weight to stakeholders (Mary \& Suganya, 2016). The ELECTRE method and its variant find extensive applications in decision-making problems, for instance, supplier selection (Fei et al., 2019; Girubha et al., 2016), service provider (Mishra et al., 2020), prioritizing health supplies (Shojaie et al., 2018), facility layout selection (Aiello \& Galante, 2006), renewable energy planning (Beccali et al., 2003) and so on.

During the use of ELECTRE I major difficulty occurred because alternatives on the different criteria are 
imprecise. ELECTRE III has more features than ELECTRE I and ELECTRE II which includes the capability to work on preference thresholds, indifference and fuzzy outranking relation (Girubha et al., 2016). The published research mainly focuses on the requirement for healthcare facility development, need for the development, and utilises basic procedure for designing facility layout and multi-criteria decision approach as an effective tool in decision making. To the best of authors' knowledge, previous research lacks in showing the layout modification in healthcare facility using mentioned procedures, methodologies, and algorithms. Moreover, no research is observed which uses ELECTRE method for the selection of best layout for the existing healthcare facility.

\section{Methodology adopted}

This research utilises a case study, Hospital-A and optimizes its layout by taking it as an MCDM problem and hence solve it. Different strategies that can be implemented for the planning and different methodologies that should be followed for optimized planning were explored through published literature. Further, a survey questionnaire was developed with the contribution from the medical professional, engineers, and consultants. The survey was distributed, and responses collected in Hospital-A from its patients, their attendants (family and friends), nursing staff as well as the doctors. The data was analysed to identify the most critical areas within the facility needing improvements. As MULTIPLE method uses the space-filling curve, it is used to form an alternative layout for an existing facility. The MULTIPLE method and Apple's layout procedure which is based on experiential learning, new layouts were generated using designing software. To understand the effectiveness of the layouts the interdepartmental relationship score for each layout was calculated.
ELECTRE is used as MCDM techniques for the proposed layouts of Hospital-A. ELECTRE method is an outranking method developed to solving the ranking problem. The method has three essential steps, namely, determining the importance of criteria, developing pairwise comparison, and arriving the ranks (Girubha et al., 2016). Compared to other decision-making methods like PROMETHEE, TOPSIS, and VIKOR, the ELECTRE methodology can make decisions with imprecise data as it uses two extreme opposite relationships like strong and weak relationships (Salminen et al., 1998). The pure concordance and discordance indices incorporate the extreme relationships for arriving at the final ranks (de Almeida, 2007). ELECTRE Method has been widely used in various ranking applications when associated with imprecise data (Fei et al., 2019; Girubha et al., 2016; Sevkli et al., 2010).

In this view, the research method has been developed by adopting ELECTRE method. Seven criteria are decided as mentioned further and weights are assigned for each criterion. The efficiency of the healthcare facility depends upon different types of process flows within the facility, so generalized flows are considered for calculation of distance and time matrix. All the seven criteria that are REL score, patient time, patient distance, staff time, staff distance, material time, material distance were incorporated in the ELECTRE method are used for finding best layout. Figure 1 shows the flow of the methodology.

\section{Case study}

The study was conducted on a healthcare facility located in Vellore, Tamilnadu, India. Overtime expansion of facility resulted in the displacement of most of the departments within the facility. This led to decreasing efficiency in handling staff, medical equipment and patients, affecting the effectiveness of the treatment. The expansions made it relevant to carry on the study for this facility.

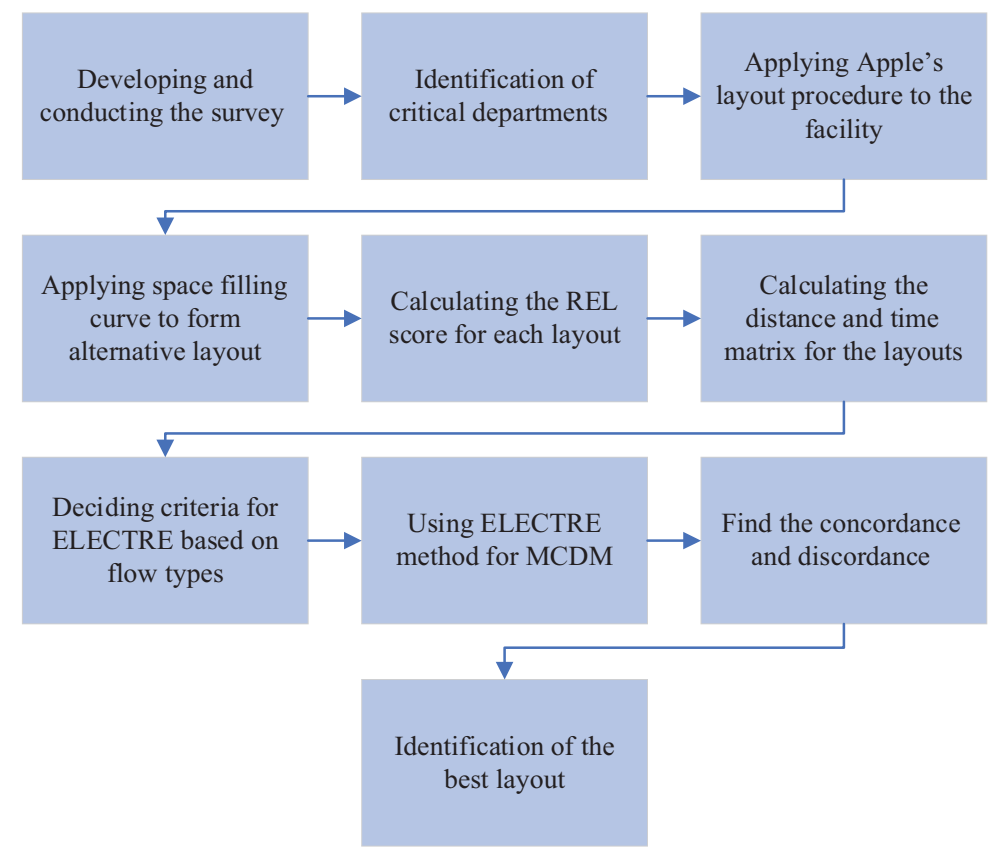

Figure 1. Flowchart for methodology 


\subsection{Survey summary and statistical analysis of survey}

A survey questionnaire was developed with the engagement of the medical professional, engineers and consultants. With approval from the hospital management, the survey was conducted among all the stakeholders that included doctors, patients, family, friends, nurses, and the management staff. The survey is analysed and interpreted both qualitatively and quantitatively to make a data-driven decision. A total of 91 people participated in the survey,

Table 1. Survey questionnaire along with statistical analysis

\begin{tabular}{|c|c|c|}
\hline No & Questions & Mean and SD \\
\hline 1 & $\begin{array}{l}\text { Does the waiting area provide } \\
\text { enough spacing for the } \\
\text { patients and their family for } \\
\text { accommodation? }\end{array}$ & $3.681319 \pm 0.929505$ \\
\hline 2 & $\begin{array}{l}\text { Does the current facility layout } \\
\text { provide a positive experience for } \\
\text { family and the visitors? }\end{array}$ & $3.538462 \pm 0.946428$ \\
\hline 3 & $\begin{array}{l}\text { The operating room is/are near } \\
\text { to the recovery and post-recovery } \\
\text { are? }\end{array}$ & $3.604396 \pm 0.941383$ \\
\hline 4 & $\begin{array}{l}\text { Does the current facility layout } \\
\text { provide a positive experience for } \\
\text { patients? }\end{array}$ & $3.483516 \pm 1.025916$ \\
\hline 5 & $\begin{array}{l}\text { Does the current facility layout } \\
\text { provide a positive experience for } \\
\text { nursing staff and managerial staff? }\end{array}$ & $3.450549 \pm 1.035629$ \\
\hline 6 & $\begin{array}{l}\text { Does the location of the } \\
\text { pneumatic tube station is well } \\
\text { planned for the operating areas? }\end{array}$ & $3.703297 \pm 0.948619$ \\
\hline 7 & $\begin{array}{l}\text { Is the central location of the } \\
\text { care station point being easily } \\
\text { accessible for all operating areas as } \\
\text { well the interrelated departments? }\end{array}$ & $3.637363 \pm 0.972014$ \\
\hline 8 & $\begin{array}{l}\text { Is anaesthesia care unit and } \\
\text { recovery area room sizes being as } \\
\text { per the requirements? }\end{array}$ & $3.802198 \pm 0.933569$ \\
\hline 9 & $\begin{array}{l}\text { The pharmacy is easily accessible } \\
\text { for in-patients and the out- } \\
\text { patients, does it provide a positive } \\
\text { experience? }\end{array}$ & $3.648352 \pm 0.911331$ \\
\hline 10 & $\begin{array}{l}\text { Is operating room being easily } \\
\text { accessible to the on-duty doctors? }\end{array}$ & $3.681319 \pm 0.998656$ \\
\hline 11 & $\begin{array}{l}\text { Do you think that the accessibility } \\
\text { of pharmacy and the operating } \\
\text { room is quick? }\end{array}$ & $3.527473 \pm 1.025678$ \\
\hline 12 & $\begin{array}{l}\text { Are data monitoring and } \\
\text { reporting system located near ORs } \\
\text { and recovery area? }\end{array}$ & $3.736264 \pm 0.916941$ \\
\hline 13 & $\begin{array}{l}\text { Is the point of contact of the staff } \\
\text { with the patients is quick and } \\
\text { accessible? }\end{array}$ & $3.802198 \pm 0.991293$ \\
\hline 14 & $\begin{array}{l}\text { Is the path of the emergency } \\
\text { section having quick access to } \\
\text { other necessary departments } \\
\text { within the facility? }\end{array}$ & $3.78022 \pm 1.019828$ \\
\hline 15 & $\begin{array}{l}\text { How is the overall experience for } \\
\text { the current facility? }\end{array}$ & $3.626374 \pm 1.007178$ \\
\hline
\end{tabular}

including 5 doctors ( 3 duty doctors and 2 specialists), 36 staff members (both nursing and management staff) and 50 patients with their families (including both In-patient and Out-patients). Table 1 shows the mean and the standard deviation of the responses recorded. The parameters considered for selecting the departments to focus on are the ones with a mean value less than 3.7 or having a standard deviation of more than 0.95 .

Based on the analysis of the survey, ICU, OT, Pharmacy, Emergency, MRD, Lab, IP Billing, Pathway and Consultancy Rooms were defined as critical departments.

\subsection{Planning alternative layouts}

Figure 2 shows the current layout, obtained from the healthcare facility under study. The departments in the current layout were given different annotations for ease of understanding which are listed in Appendix 1. Based on the survey findings of the critical departments, 4 layouts have been proposed in Figures 3, 4, 5 and 6, with the description of changes and the reason for those changes in Tables 2, 3, 4, and 5, respectively.

Figure 3 shows the proposed layout for the facility (Plan 1). Table 2 lists the changes in the current layout
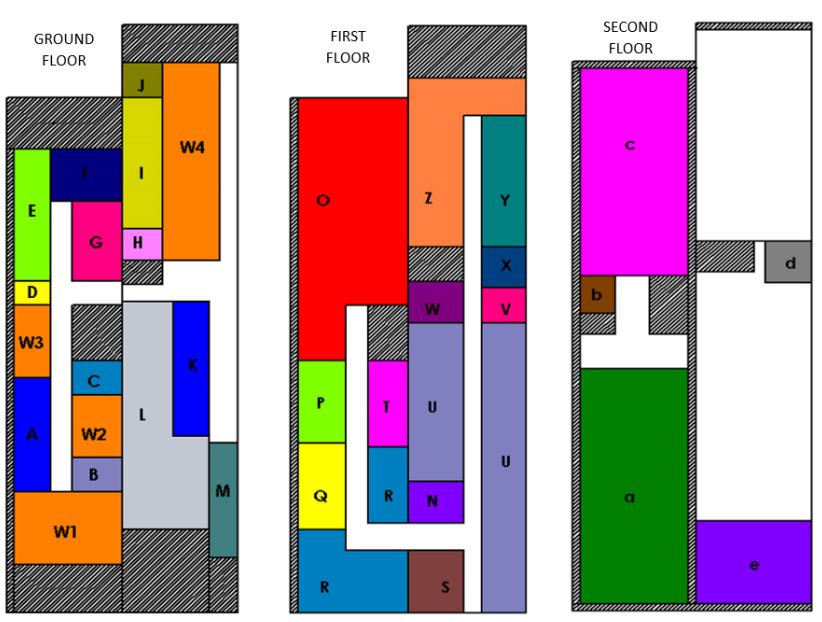

Figure 2. Current layout
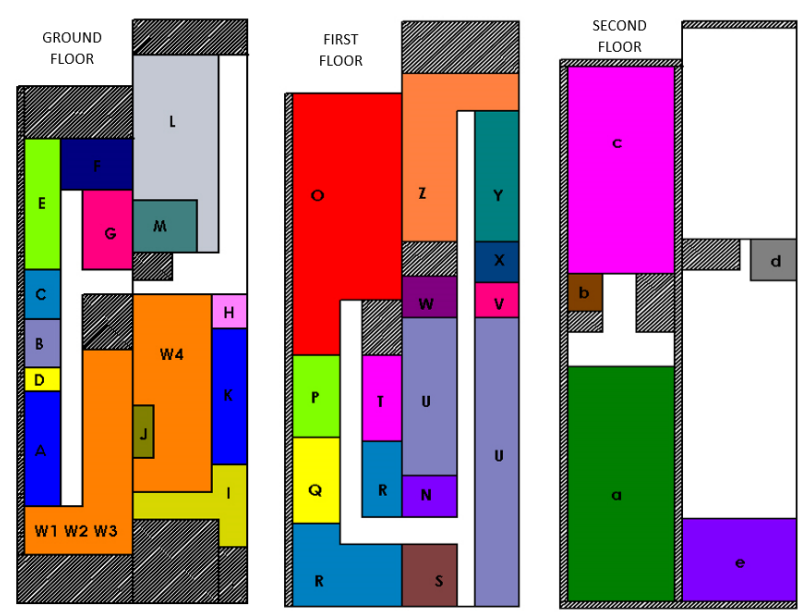

Figure 3. Proposed layout 1 (Plan 1) 
according to the proposed layout (Plan 1) and the reason stating the need for necessary changes.

Figure 4 shows another proposed layout for the facility (Plan 2). Table 3 lists the changes in the current layout according to the proposed layout (Plan 2) and the reason stating the need for those changes.
Figure 5 shows the proposed layout for the facility (Plan 3). Table 4 presents the changes in the current layout according to the proposed layout (Plan 3 ) and the reason stating the need for those changes.

Figure 6 shows the proposed layout for the facility (Plan 4). Table 5 lists the changes in the current layout

Table 2. Changes made in Plan 1 and reasons

\begin{tabular}{|c|l|l|}
\hline $\begin{array}{c}\text { Sl. } \\
\text { No }\end{array}$ & \multicolumn{1}{|c|}{ Changes } & \multicolumn{1}{|c|}{ Reason } \\
\hline 1 & $\begin{array}{l}\text { Pharmacy department and the waiting area for the IP family } \\
\text { (W4) has been interchanged with the emergency department } \\
\text { and the hi-tech lab }\end{array}$ & $\begin{array}{l}\text { To increase the accessibility of the EMR department from } \\
\text { the back door as most of the emergency cases arrive from } \\
\text { the back door in the facility and to increase the nearness of } \\
\text { the lab from the MOT and OT }\end{array}$ \\
\hline 2 & $\begin{array}{l}\text { The place where the EMR department was located has been } \\
\text { converted to the waiting area and the pathways for the EMR } \\
\text { department have been occupied by the consulting rooms, IP } \\
\text { billing and Pharmacy in L shape }\end{array}$ & $\begin{array}{l}\text { To provide more waiting area for the OP's and IP's and at the } \\
\text { same time making the pharmacy much more accessible than } \\
\text { before to serve both OP and IP with 2-way access }\end{array}$ \\
\hline 3 & $\begin{array}{l}\text { The waiting area for both the new consultancy and new } \\
\text { pharmacy location are separated }\end{array}$ & $\begin{array}{l}\text { Separated areas so that the consulting room are accessible to } \\
\text { the OP's and the pharmacy can be used for both }\end{array}$ \\
\hline 4 & $\begin{array}{l}\text { The consultancy room 3, the manager room and the children } \\
\text { section have been shifted to the waiting area 3 and the open } \\
\text { space has been used as a waiting area }\end{array}$ & $\begin{array}{l}\text { To increase the capacity for crowd management within } \\
\text { the hospital and to have more capacity to handle patients. } \\
\text { Opening up more free areas in both the building results in } \\
\text { enormous crowd handling }\end{array}$ \\
\hline 5 & Canteen has been placed in front of the pharmacy & Making it accessible for both IP and OP \\
\hline
\end{tabular}

Table 3. Changes made in Plan 2 and reasons

\begin{tabular}{|l|l|l|}
\hline $\begin{array}{c}\text { Sl. } \\
\text { No }\end{array}$ & \multicolumn{1}{|c|}{ Changes } & \multicolumn{1}{|c|}{ Reason } \\
\hline 1 & $\begin{array}{l}\text { The lab is moved in place of the IP billing section and } \\
\text { pharmacy inventory section, the pharmacy inventory section } \\
\text { occupies the area of the canteen and the canteen has been } \\
\text { shifted beside that }\end{array}$ & $\begin{array}{l}\text { The main reason for doing this is because the lab is highly } \\
\text { related to the MOT, OT and the EMR department and hence } \\
\text { to reduce the distance and time, the lab was given that space }\end{array}$ \\
\hline 2 & $\begin{array}{l}\text { The EMR and consulting rooms have been flipped at their } \\
\text { position and the open space i.e. in place of the lab, that area } \\
\text { is being used for the waiting area for the consultancy rooms }\end{array}$ & $\begin{array}{l}\text { The flipping gives a huge advantage as it gives higher } \\
\text { accessibility to the backdoor from the EMR departments and } \\
\text { also to the MOT and OT apart from that the waiting area for } \\
\text { the consultancy does do not clash with the EMR flow }\end{array}$ \\
\hline 3 & $\begin{array}{l}\text { The scan room has been shifted to the ground floor in the } \\
\text { waiting area } 3 \text { and the IP billing has been shifted to the first } \\
\text { floor in place of the scan room }\end{array}$ & $\begin{array}{l}\text { To increase the convenience of the IP family, IP billing is } \\
\text { shifted on the first floor and its access with the MRD section. } \\
\text { It also brings scan nearer to the OP's }\end{array}$ \\
\hline 4 & $\begin{array}{l}\text { The consulting room } 3 \text { and the manager area has been shifted } \\
\text { to the waiting area } 3 \text { and the consulting room } 6 \text { has been } \\
\text { shifted to the waiting area 2 (which is practically occupied) }\end{array}$ & $\begin{array}{l}\text { Giving a better capacity handling and to have the patients } \\
\text { within the facility without much crowd in the pathways of } \\
\text { the facility }\end{array}$ \\
\hline
\end{tabular}
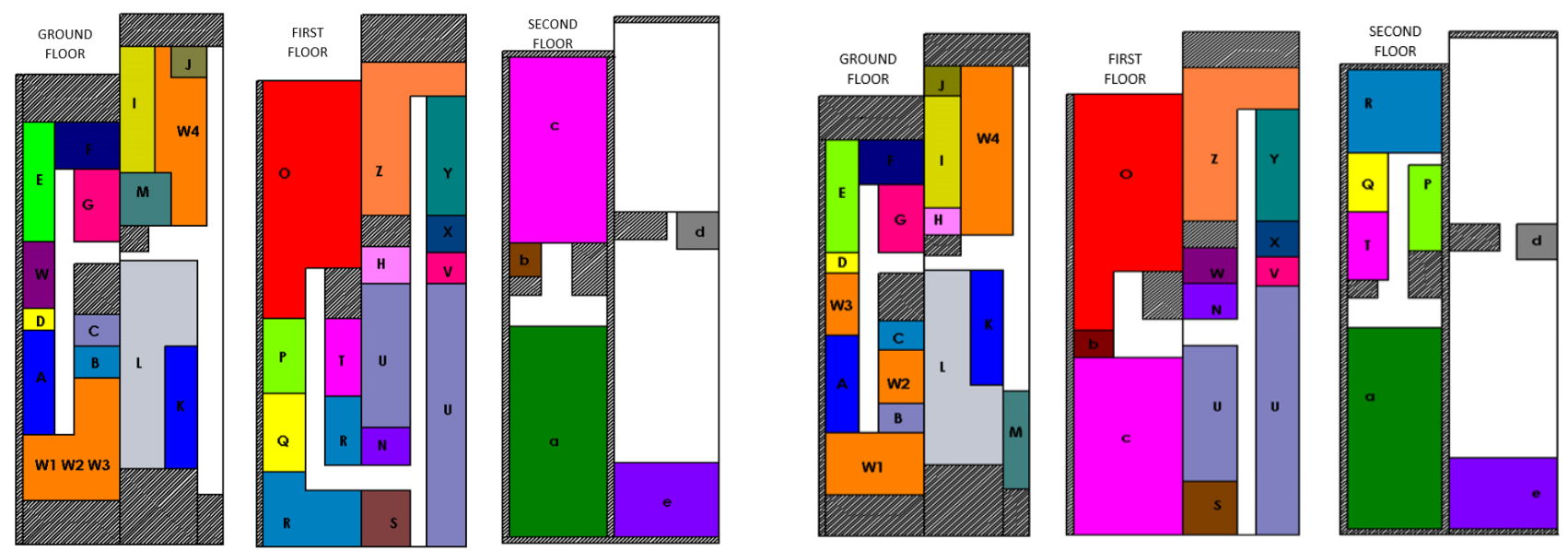

Figure 4. Proposed layout 2 (Plan 2)

Figure 5. Proposed layout 3 (Plan 3) 
Table 4. Changes made in Plan 3 and reasons

\begin{tabular}{|c|l|l|}
\hline $\begin{array}{c}\text { Sl. } \\
\text { No }\end{array}$ & \multicolumn{1}{|c|}{ Changes } & Reason \\
\hline 1 & $\begin{array}{l}\text { ICU is shifted to the first floor in place of the wards in front } \\
\text { of OT. Also, the endoscopy section is shifted to the first floor }\end{array}$ & $\begin{array}{l}\text { To give better accessibility to the ICU with all the critical } \\
\text { areas and its higher accessibility with the wards to shift } \\
\text { critical patients nearby }\end{array}$ \\
\hline 2 & $\begin{array}{l}\text { The private and the semi-private wards are shifted on the } \\
\text { second floor in place of the ICU along with the staff rooms } \\
\text { for closer surveillance of the patients in the wards }\end{array}$ & $\begin{array}{l}\text { The criticalness of other patients is not as high as compared } \\
\text { to the ICU patients and them being near to the nursing } \\
\text { centre resulting in not much difference while shifting }\end{array}$ \\
\hline 3 & $\begin{array}{l}\text { The path on the first floor in the ward area is shifted near } \\
\text { to the lift, making it a central location for the movement of } \\
\text { stretchers and trolleys }\end{array}$ & $\begin{array}{l}\text { The pathway is made wider to 8 feet so that the accessibility } \\
\text { with the lift and the OT, ICU on a stretcher can be managed } \\
\text { easily and quickly }\end{array}$ \\
\hline 4 & $\begin{array}{l}\text { The nursing centre is shifted near to the path and in place of } \\
\text { a private ward which will be shifted at the backside }\end{array}$ & $\begin{array}{l}\text { Giving central access to the wards and other departments } \\
\text { resulting in quick access and reducing the staff flow timing, } \\
\text { making it a central location }\end{array}$ \\
\hline
\end{tabular}

Table 5. Changes made in Plan 4 and reasons

\begin{tabular}{|l|l|l|}
\hline $\begin{array}{c}\text { Sl. } \\
\text { No }\end{array}$ & \multicolumn{1}{|c|}{ Changes } & \multicolumn{1}{|c|}{ Reason } \\
\hline 1 & $\begin{array}{l}\text { Pharmacy department and the waiting area for the IP family } \\
\text { (W4) has been interchanged with the emergency department } \\
\text { and the lab }\end{array}$ & $\begin{array}{l}\text { To increase the accessibility of the EMR department from } \\
\text { the back door as most of the emergency cases arrive from } \\
\text { the back door in the facility and to increase the nearness of } \\
\text { the lab from the MOT and OT }\end{array}$ \\
\hline 2 & $\begin{array}{l}\text { EMR department has been converted to the waiting area and } \\
\text { the pathways for the EMR department have been occupied } \\
\text { by the consulting rooms, IP billing and Pharmacy in L shape }\end{array}$ & $\begin{array}{l}\text { To provide more amount of area that is occupied for waiting } \\
\text { for the OP's and IP's and at the same time making the } \\
\text { pharmacy much more accessible than before to serve both } \\
\text { OP and IP with two-way access }\end{array}$ \\
\hline 3 & $\begin{array}{l}\text { The waiting area for both the new consultancy and new } \\
\text { pharmacy location are separated }\end{array}$ & $\begin{array}{l}\text { Areas are separated so the consulting rooms are accessible to } \\
\text { the OP's and the pharmacy can be used for both }\end{array}$ \\
\hline 4 & $\begin{array}{l}\text { Consultancy room 3, manager room and the children section } \\
\text { have been shifted to the waiting area 3 }\end{array}$ & $\begin{array}{l}\text { To increase the crowd handling within the hospital and to } \\
\text { have more capacity for patients }\end{array}$ \\
\hline 5 & Canteen has been placed in front of the pharmacy & Making it accessible for both IP and OP \\
\hline
\end{tabular}
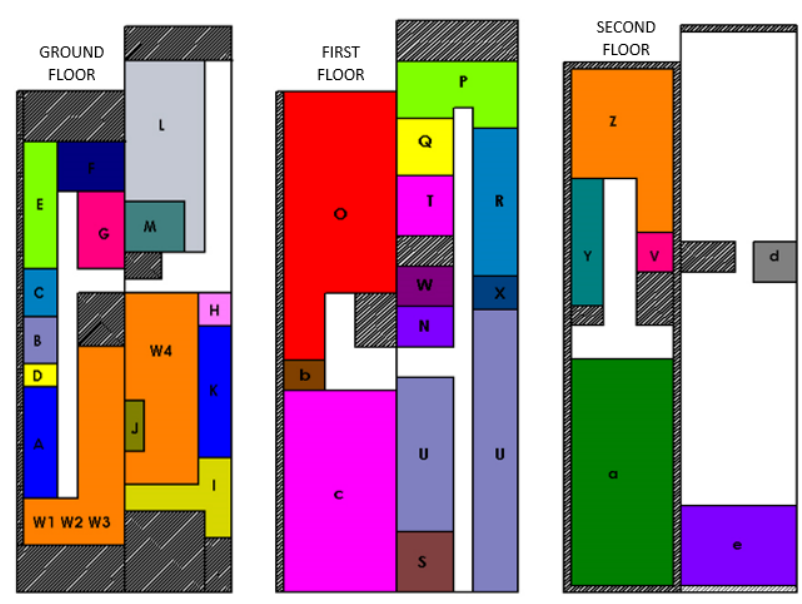

Figure 6. Proposed layout 4 (Plan 4) according to the proposed layout (Plan 4) and the reason stating the need for those changes.

With each proposed layout aiming to achieve better flow, it is vital to understand the types of flows in a healthcare facility.

\subsection{Types of flows}

There are different types of flow pattern that can be observed within a healthcare facility and to understand all types of flows within a facility makes it complicated to simulate processes and summarize. Therefore, in this research, the flow types observed in the Hospital-A are generalized and being considered after consulting the medical professionals and prolonged observations.

\subsubsection{Material flow}

Figure 7 shows the generalized types of material flow. 


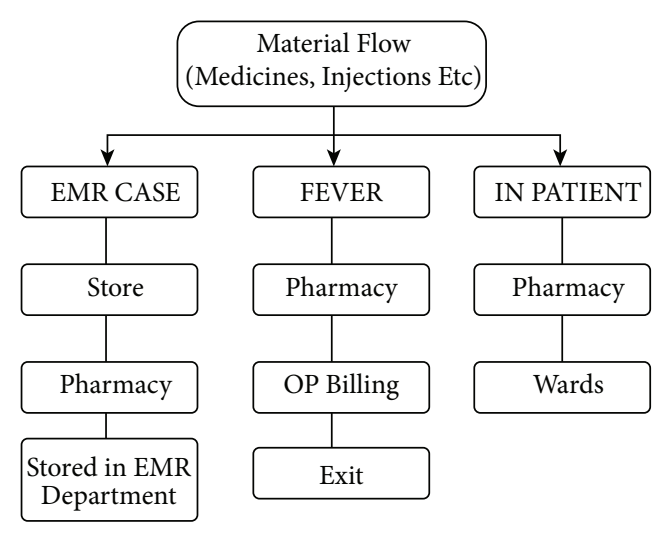

Figure 7. Types of material flow

\subsubsection{Staff flow}

Figure 8 shows the generalized types of staff flow.

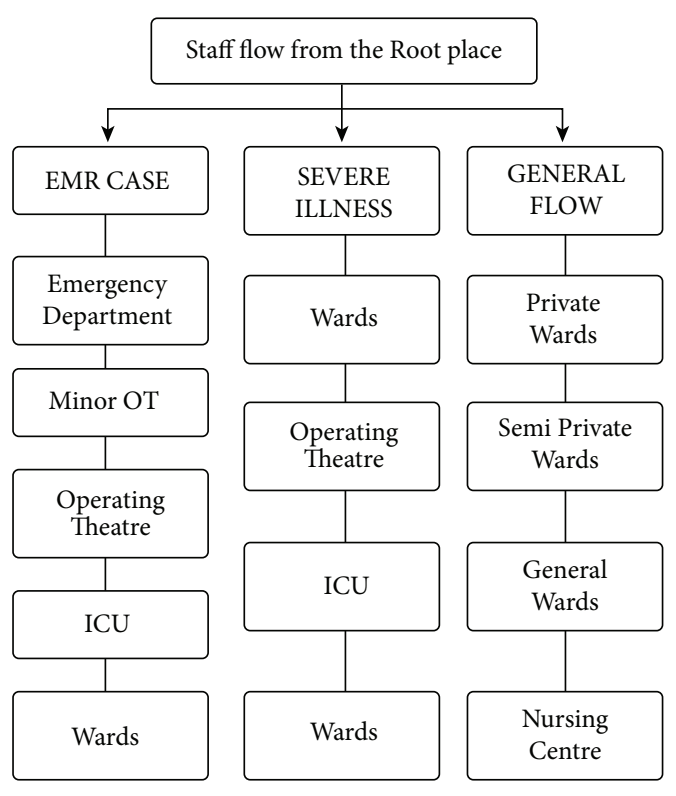

Figure 8. Types of staff flow

\subsubsection{Patient flow}

Figure 9 shows the generalized types of patient flow.

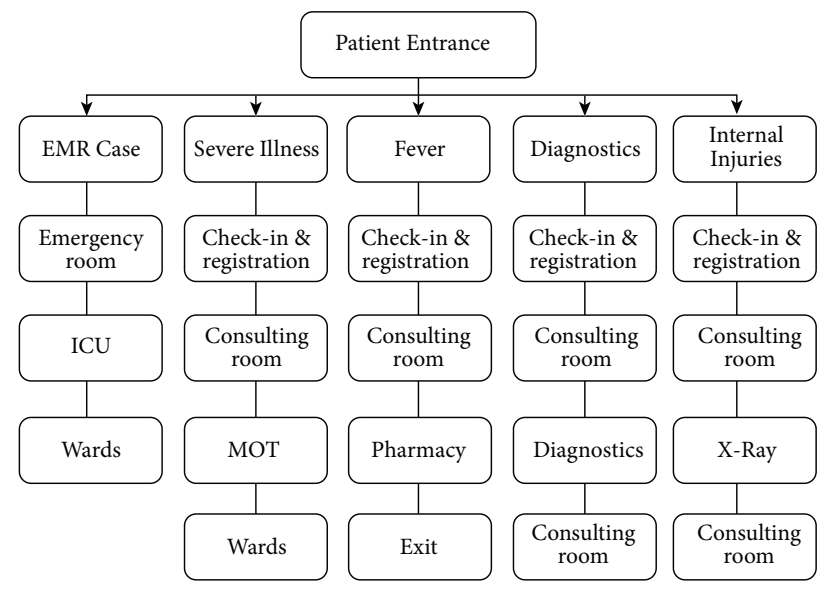

Figure 9. Types of patient flow

\subsection{Apple's layout procedure}

Apple's layout procedure is utilised to further analyse the generalized flows drawn from the list of different flows observed in the facility, as mentioned in Figure 10. Basic data such as area for each department and interdepartmental satisfactory level score is collected and analyzed. Figure 10 shows the flowchart for Apple's layout procedure.
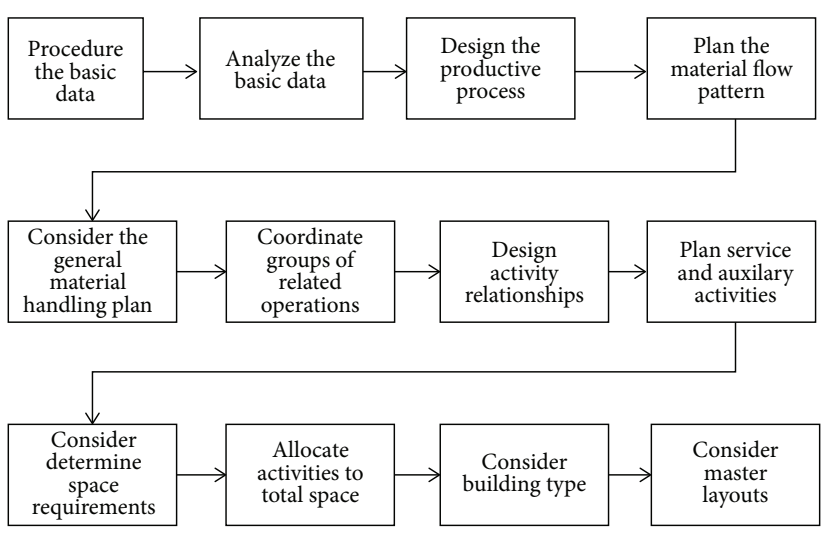

Figure 10. Flowchart for Apple’s layout procedure

\subsubsection{Distance matrix calculation}

There are 4 types of wards present in the facility which plays a major role in all three types of flows namely material, staff, and patients. The average distance from a department to the wards are taken into consideration as shown in Appendix 2. After defining the X and Y coordinate, the absolute rectilinear distances between the two departments is calculated and for the total distance, the average was taken into consideration. If the departments are placed on different floors (in this case pharmacy and all wards are on different floors), a defined floor change value (20 for every added floor) is added to the rectilinear distance. Similar calculations were done for all the cases where there is a flow between wards and that particular department mainly being Intensive care unit (ICU), Minor Operating Theatre, Operation Theatre, Nursing and Pharmacy. Once all the calculations of distances were completed for all the layouts further distances were calculated for all three types of flows.

Appendix 3 shows the average distance travelled for material flow in the three cases. Firstly, the coordinates for the departments included in the material flow for all the three cases were calculated. Considering these coordinates rectilinear distances were found between the departments in the flow for all cases. Floor change defined values (20 for every added floor) were added if any. Finally taking into consideration all the cases in material flow, total distance was calculated. Once total distance was obtained, the average distance for the material flow for the current layout was found. Similar calculations were carried out for all the proposed layouts as well.

Appendix 4 shows the average distance travelled for staff flow in the three cases. Firstly, the coordinates for the 
departments included in the staff flow for all the three cases were calculated. Considering these coordinates rectilinear distances were found between the departments in the flow for all the cases. Floor change defined values (20 for every added floor) were added if any. Finally taking into consideration all the cases in staff flow, total distance was calculated. Once total distance was obtained, the average distance for the staff flow for the current layout was found. Similar calculations were carried out for all the proposed layouts as well.

Appendix 5 shows the average distance travelled for patient flow in the three cases. The coordinates for the departments included in the patient flow for all the three cases were calculated. Considering these coordinates rectilinear distances were found between the departments in the flow for all the cases. Floor change defined values (20 for every added floor) were added if any. Finally taking into consideration all the cases inpatient flow, total distance was calculated. Once total distance was obtained, the average distance for the patient flow for the current layout was found. Similar calculations were carried out for all the proposed layouts as well.

Appendix 3-5 presents the calculations of distances for each of the three flows namely material flow, staff flow, and patients flow for the current layout of the healthcare facility. Similar calculations were done for all the proposed layouts and the resulting values are tabulated in Table 6 which includes the current layout as well as all the proposed layouts. All the values of distances are obtained from the overall distance matrix as seen in Table 6 with all the calculations, using Microsoft Excel.

\subsubsection{Time matrix calculation}

The time values are calculated considering approximate values for speeds of material, staff, and patients. The speed in feet/sec is assumed as mentioned in Appendix 6. Using these assumed speeds in feet/sec, the time matrix values are obtained as tabulated in Appendix 7.

\subsubsection{Relationship scores for interdepartmental relation score calculation}

Based on the testimonials from experts in a healthcare facility, relationship scores were obtained as mentioned in Appendix 8 for the current layout of the facility. The calculation was done by taking into consideration all the departments on a particular floor and its relationship with the adjacently placed department. Also, in case of departments placed adjacent to stairs and lifts, the adjacent departments to the stairs and lifts on the immediate next floor were taken into consideration under floor change for relationship score. Thus, the total score for a particular floor was calculated. A similar methodology was applied for all the floors in current and all the four proposed layouts and the summarized relationship matrix values have been tabulated in Table 7 .

Table 7. Overall interdepartmental relationship score matrix

\begin{tabular}{|l|c|c|c|c|c|}
\hline \multicolumn{1}{|c|}{ Layout } & Current & Plan 1 & Plan 2 & Plan 3 & Plan 4 \\
\hline Ground floor & 37 & 42 & 38 & 51 & 40 \\
\hline First floor & 13 & 12 & 19 & 15 & 22 \\
\hline Second floor & -4 & -4 & -4 & 1 & 0 \\
\hline Total & 46 & 50 & 53 & 67 & 62 \\
\hline
\end{tabular}

All the required data values based on which decision matrix is formed are mentioned in Table 8. This table lists the average distance and average time values for all the three types of flows for the current layout and all the proposed layouts - Plan 1, Plan 2, Plan 3 and Plan 4.

Table 8. Consolidated average distance and average time matrix

\begin{tabular}{|c|c|c|c|c|c|c|}
\hline Criteria & \multicolumn{3}{|c|}{ Average distance matrix } & \multicolumn{3}{|c|}{ Average time matrix } \\
\hline Layout & 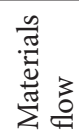 & 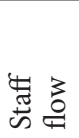 & 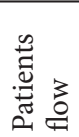 & 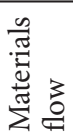 & 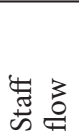 & 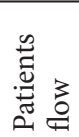 \\
\hline Original & 120 & 471 & 268 & 45 & 163 & 94 \\
\hline Plan 1 & 116 & 453 & 219 & 39 & 158 & 75 \\
\hline Plan 2 & 125 & 466 & 261 & 47 & 161 & 93 \\
\hline Plan 3 & 141 & 472 & 297 & 52 & 156 & 102 \\
\hline Plan 4 & 116 & 403 & 227 & 40 & 138 & 77 \\
\hline
\end{tabular}

Table 6. Overall distance matrix

\begin{tabular}{|c|c|c|c|c|c|c|c|c|c|c|c|}
\hline & \multicolumn{3}{|c|}{ Materials flow } & \multicolumn{3}{|c|}{ Staff flow } & \multicolumn{5}{|c|}{ Patients flow } \\
\hline & $\sum_{i=1}^{\Im}$ & 离 & $\Leftrightarrow$ & $\sum_{\mid=1}^{\mathscr{I}}$ & 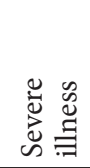 & 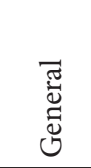 & $\sum_{\mid=1}^{\mathscr{s}}$ & 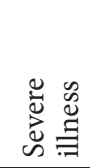 & 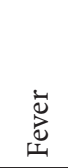 & 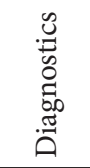 & 䄊. \\
\hline Current & 88.5 & 135.5 & 136.1 & 487.6 & 580.3 & 344.5 & 418.6 & 249.1 & 270 & 217 & 185 \\
\hline Plan 1 & 112 & 70 & 164.6 & 434.6 & 580.4 & 344.5 & 336.6 & 239.6 & 121 & 214.5 & 182.5 \\
\hline Plan 2 & 82.5 & 145.5 & 146.1 & 471.6 & 580.4 & 344.5 & 386.6 & 245.6 & 279 & 213.5 & 181.5 \\
\hline Plan 3 & 88.5 & 135.5 & 200.3 & 522.8 & 647.5 & 245.5 & 479.8 & 333 & 270 & 217 & 185 \\
\hline Plan 4 & 112 & 70 & 167.1 & 444.4 & 465 & 298.5 & 372.4 & 242.1 & 121 & 214.5 & 182.5 \\
\hline
\end{tabular}


Table 9 shows the decision matrix $\mathrm{z}$ which is then used for ELECTRE Analysis.

Table 9. Decision matrix

\begin{tabular}{|c|c|c|c|c|c|c|c|}
\hline Criteria & & & $\ddot{\Xi}$ & 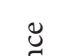 & & & \\
\hline Layout & 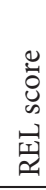 & 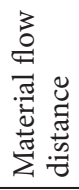 & 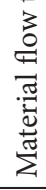 & 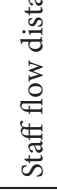 & 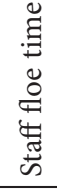 & 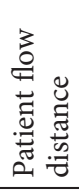 & 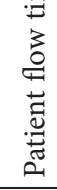 \\
\hline Original & 46 & 120 & 45 & 471 & 163 & 268 & 94 \\
\hline Plan 1 & 50 & 116 & 39 & 453 & 158 & 219 & 75 \\
\hline Plan 2 & 53 & 125 & 47 & 466 & 161 & 261 & 93 \\
\hline Plan 3 & 67 & 141 & 52 & 472 & 156 & 297 & 102 \\
\hline Plan 4 & 62 & 116 & 40 & 403 & 138 & 227 & 77 \\
\hline
\end{tabular}

\section{ELECTRE method analysis and calculations}

Step 1: Normalization decision matrix

Decision matrix $Z(m \times n)$, where $m$ represents the number of alternatives and $n$ states the criteria, then the matrix $z_{i j}$ can be normalized using the following equation:

$$
z_{i j}=\frac{x_{i j}}{\sqrt{\sum_{i=1}^{m} x_{i j}^{2}}} \text { for } i=1,2,3, \ldots m \text { and }
$$$$
j=1,2,3, \ldots n \text {. }
$$

Matrix $Z(m \times n)$ obtained normalized matrix as shown in Table 10.

\section{Step 2: Formation of the weighted normalized matrix}

Table 11 shows the calculation for assigning weight to each criterion. The weights are taken from three different experts and average is taken for ELECTRE analysis.

Each column of the matrix $Z$ is multiplied by the weight given for the particular criterion as shown in $\mathrm{Ta}-$ ble 11 to form the weighted normalized matrix. It is done by using the following equation:

$$
v_{i j}=w_{i} \times z_{i j}
$$

Table 12 shows the resulting weighted decision matrix.

Table 10. Normalized decision matrix

\begin{tabular}{|l|c|c|c|c|c|c|c|}
\cline { 1 - 7 } \multicolumn{1}{r|}{ Criteria } & \multirow{2}{*}{ Layout } & C1 & C3 & C4 & C5 & C6 & C7 \\
\cline { 1 - 7 } Original (L1) & 0.3664 & 0.4330 & 0.4483 & 0.4642 & 0.4672 & 0.4683 & 0.4742 \\
\hline Plan 1 (L2) & 0.3983 & 0.4168 & 0.3907 & 0.4468 & 0.4545 & 0.3825 & 0.3776 \\
\hline Plan 2 (L3) & 0.4222 & 0.4498 & 0.4710 & 0.4590 & 0.4633 & 0.4566 & 0.4682 \\
\hline Plan 3 (L4) & 0.5337 & 0.5102 & 0.5193 & 0.4653 & 0.4496 & 0.5190 & 0.5146 \\
\hline Plan 4 (L5) & 0.4939 & 0.4198 & 0.3935 & 0.3970 & 0.3979 & 0.3958 & 0.3856 \\
\hline
\end{tabular}

\begin{tabular}{|c|c|c|c|c|c|}
\hline \multirow{2}{*}{ Code } & \multirow{2}{*}{ Criteria } & \multicolumn{3}{|c|}{ Weight } & \multirow{2}{*}{ Average } \\
\hline & & Expert 1 & Expert 2 & Expert 3 & \\
\hline $\mathrm{C} 1$ & Interdepartmental relation score & 0.35 & 0.3 & 0.4 & 0.35 \\
\hline $\mathrm{C} 2$ & Material flow distance & 0.15 & 0.1 & 0.05 & 0.1 \\
\hline $\mathrm{C} 3$ & Material flow time & 0.05 & 0.05 & 0.05 & 0.05 \\
\hline $\mathrm{C} 4$ & Staff flow distance & 0.15 & 0.2 & 0.1 & 0.15 \\
\hline $\mathrm{C} 5$ & Staff flow time & 0.05 & 0.05 & 0.05 & 0.05 \\
\hline C6 & Patients flow distance & 0.2 & 0.25 & 0.3 & 0.25 \\
\hline C7 & Patients flow time & 0.05 & 0.05 & 0.05 & 0.05 \\
\hline
\end{tabular}

Table 11. Criteria weightage formulated with the help of experts

\begin{tabular}{|c|c|c|c|c|c|c|c|}
\hline Criteria & \multirow{2}{*}{$\mathrm{C} 1$} & \multirow{2}{*}{$\mathrm{C} 2$} & \multirow{2}{*}{$\mathrm{C} 3$} & \multirow{2}{*}{$\mathrm{C} 4$} & \multirow{2}{*}{$\mathrm{C} 5$} & \multirow{2}{*}{ C6 } & \multirow{2}{*}{$\mathrm{C} 7$} \\
\hline Layout & & & & & & & \\
\hline Original (L1) & 0.1283 & 0.0433 & 0.0224 & 0.0696 & 0.0234 & 0.1171 & 0.0237 \\
\hline Plan 1 (L2) & 0.1394 & 0.0417 & 0.0195 & 0.0670 & 0.0227 & 0.0956 & 0.0189 \\
\hline Plan 2 (L3) & 0.1478 & 0.0450 & 0.0235 & 0.0688 & 0.0232 & 0.1141 & 0.0234 \\
\hline Plan 3 (L4) & 0.1868 & 0.0510 & 0.0260 & 0.0698 & 0.0225 & 0.1297 & 0.0257 \\
\hline Plan 4 (L5) & 0.1729 & 0.0420 & 0.0197 & 0.0595 & 0.0199 & 0.0990 & 0.0193 \\
\hline
\end{tabular}

Table 12. Weighted decision matrix 


\section{Step 3: Finding concordance and discordance index}

The set of criteria $j$ is divided into two subsets namely concordance and discordance for each pair of alternatives $p$ and $q(p, q=1,2,3, \ldots, m$ and $p \neq 1)$. The criterion in each alternative will include in concordance set when:

$$
c_{p q}=\left\{j \mid y_{p j} \leq y_{q j}\right\} \text {, for } j=1,2,3, \ldots, n .
$$

Otherwise, the criterion in each alternative will include in discordance set, when:

$$
d_{p q}=\left\{\mid y_{p j}<y_{q j}\right\}, \text { for } j=1,2,3, \ldots, n .
$$

\section{Step 4: Calculation of concordance and discordance} matrices

Concordance matrix is found out by adding all the weights included in the concordance subset which can be shown by the following equation:

$$
C_{p q}=\sum_{j \in C_{p q}} W_{j} .
$$

Therefore, the resulting concordance matrix is shown in Table 13.

Table 13. Concordance matrix

\begin{tabular}{|l|c|c|c|c|c|}
\hline & L1 & L2 & L3 & L4 & L5 \\
\hline Original (L1) & 0 & 0.00 & 0.15 & 0.60 & 0.00 \\
\hline Plan 1 (L2) & 1.00 & 0 & 0.65 & 0.60 & 0.35 \\
\hline Plan 2 (L3) & 0.85 & 0.35 & 0 & 0.60 & 0.00 \\
\hline Plan 3 (L4) & 0.40 & 0.40 & 0.40 & 0 & 0.35 \\
\hline Plan 4 (L5) & 1.00 & 0.55 & 1.00 & 0.65 & 0 \\
\hline
\end{tabular}

Similarly, the elements in the discordance matrix (see Table 14) are calculated by dividing the maximum of the difference of the criterion value included in the discordance subset by maximum difference value in existing criteria.

Table 14. Discordance matrix

\begin{tabular}{|l|c|c|c|c|c|}
\hline & L1 & L2 & L3 & L4 & L5 \\
\hline Original (L1) & 0 & 1.00 & 1.00 & 1.00 & 1.00 \\
\hline Plan 1 (L2) & 0.00 & 0 & 0.45 & 1.00 & 1.00 \\
\hline Plan 2 (L3) & 0.09 & 1.00 & 0 & 1.00 & 1.00 \\
\hline Plan 3 (L4) & 0.22 & 0.72 & 0.40 & 0 & 1.00 \\
\hline Plan 4 (L5) & 0.00 & 0.10 & 0.00 & 0.45 & 0 \\
\hline
\end{tabular}

Step 5: Determining the dominant concordance matrix and dominant discordance matrix

The $c$ bar and $d$ bar values, also called as threshold values are determined by the following equations:

$$
\underline{c}=\frac{\sum_{p=1}^{n} \sum_{q=1}^{n} c_{p q}}{m(m-1)},
$$

so, calculated $c$ bar value is 0.495 .

$$
\underline{d}=\frac{\sum_{p=1}^{n} \sum_{q=1}^{n} d_{p q}}{m(m-1)},
$$

and calculated $d$ bar value is 0.6213 .

The value of each element of dominant concordance matrix $S$ is determined as the following equation:

$$
s_{p q}=1 \text {, if } c_{p q} \geq \underline{c} \text { and } s_{p q}=0 \text {, if } c_{p q}<\underline{c} \text {. }
$$

The obtained dominant concordance matrix is shown in Table 15.

Table 15. Dominant concordance matrix

\begin{tabular}{|l|c|c|c|c|c|}
\hline & L1 & L2 & L3 & L4 & L5 \\
\hline Original (L1) & 0 & 0 & 0 & 1 & 0 \\
\hline Plan 1 (L2) & 1 & 0 & 1 & 1 & 0 \\
\hline Plan 2 (L3) & 1 & 0 & 0 & 1 & 0 \\
\hline Plan 3 (L4) & 0 & 0 & 0 & 0 & 0 \\
\hline Plan 4 (L5) & 1 & 1 & 1 & 1 & 0 \\
\hline
\end{tabular}

Similarly, the value of each element of dominant discordance matrix $T$ is determined as the following equation:

$$
t_{p q}=1 \text {, if } d_{p q} \leq \underline{d} \text { and } t_{p q}=0 \text {, if } d_{p q}>\underline{d} \text {. }
$$

The obtained dominant discordance matrix is shown in Table 16.

Table 16. Dominant discordance matrix

\begin{tabular}{|l|c|c|c|c|c|}
\hline & L1 & L2 & L3 & L4 & L5 \\
\hline Original (L1) & 1 & 0 & 0 & 0 & 0 \\
\hline Plan 1 (L2) & 1 & 1 & 1 & 0 & 0 \\
\hline Plan 2 (L3) & 1 & 0 & 1 & 0 & 0 \\
\hline Plan 3 (L4) & 1 & 0 & 1 & 1 & 0 \\
\hline Plan 4 (L5) & 1 & 1 & 1 & 1 & 1 \\
\hline
\end{tabular}

Step 6: Determining the aggregate dominance matrix

The aggregate dominant matrix $U$ is determined by multiplying each matrix element ' $s$ ' of matrix $S$ with matrix element ' $t$ ' of matrix $T$ as per the following equation:

$$
u_{p q}=s_{p q} \times t_{p q} .
$$

The obtained aggregated matrix is shown in Table 17.

Table 17. Aggregated matrix

\begin{tabular}{|l|l|l|l|l|l|}
\hline & \multicolumn{1}{|c|}{ L1 } & \multicolumn{1}{c|}{ L2 } & \multicolumn{1}{c|}{ L3 } & \multicolumn{1}{c|}{ L4 } & \multicolumn{1}{c|}{ L5 } \\
\hline Original (L1) & 0 & 0 & 0 & 0 & 0 \\
\hline Plan 1 (L2) & 1 & 0 & 1 & 0 & 0 \\
\hline Plan 2 (L3) & 1 & 0 & 0 & 0 & 0 \\
\hline Plan 3 (L4) & 0 & 0 & 0 & 0 & 0 \\
\hline Plan 4 (L5) & 1 & 1 & 1 & 1 & 0 \\
\hline
\end{tabular}

This matrix shows that: Plan 1 is better than Original and Plan 2, Plan 2 is better than Original, and Plan 4 is better than Original, Plan 1, Plan 2 and Plan 3. 


\section{Results and discussion}

In this research, multiple approaches are used while keeping ELECTRE method for MCDA. With the consultation of experts from medical, engineering and consultants, a survey was conducted Hospital-A to find the critical areas. With the identification of critical areas, the new plans were generated using Apple's layout procedure and spacefilling curve (MULTIPLE methods). Amongst all 4 layouts generated, Plan 1 focused on the ground floor with changes in the emergency department and the Pharmacy. Plan 2 had interchanging of the department on both the first and ground floor focusing on the Emergency Department and scan room to increase the accessibility. Plan 3 focused more on increasing the accessibility of the critical care departments. For Plan 4, Plan 1 was completely adopted, keeping the critical areas together, ICU and OT, and the wards were replaced with MRD and Canteen. This resulted in the higher accessibility of the wards with the point of care and hence the Plan 4 is the most optimized plans from all the 4 plans.

After analysing the floor plans, Plan 3 had the highest relation score followed by Plan 4 and as the relationship was being provided by experienced medical professionals of Hospital-A, the criterion has been given the highest weighting. The time and travelling distance for material flow were 40 seconds and 116 meters respectively which was equivalent for both Plan 1 and Plan 4. In the case of staff flow, Plan 4 was much better than Plan 1 with a time difference of 20 seconds. For inpatient flow Plan 1 was better than Plan 4 although the difference was just by 2 seconds. Hence making Plan 4 relatively efficient than Plan 1 in terms of time as well as the distance travelled.

The ELECTRE method was then implemented to find the weighted decision matrix for each of the following plans and calculating the concordance and discordance matrix. Based on the results, Plan 4 has been identified as the best-outranked plan.
Figure 11 shows the comparison of all the plan along with the criteria. Results were obtained through normalization of the matrix. Wherein the criteria 1 is based on the relationship score, the best layout from the above is Plan 3 followed by Plan 4 and with the least score to the original plan. Whereas the criteria 2 to 7 are negative parameter wherein the higher score the more negative impact it puts on the layout. In criteria 2, Plan 4 has the least score hence making it the best plan and Plan 3 has the highest score hence making it the least feasible plan. Similarly, for criteria 3 best is Plan 1 followed by Plan 4 and Plan 3 is least feasible. In criteria 4 and 5 one can observe that Plan 4 is the best and the original plan is least feasible. In Criteria 6 and 7, Plan 3 has the highest score and Plan 1 is the best, closely followed by Plan 4 . Although Plan 1 and Plan 4 are having almost equal positive criteria, while considering the best plan, looking closely at Figure 11, one can observe that in Criteria 1, 4 and 5 the marginal difference between the values of Plan 1 and Plan 4 are high, hence from the graph (see Figure 11), one can find that the best plan that the ELECTRE method produced using the given criteria is Plan 4.

To summarize the results above one can say that Plan 1 is better than the Original Plan, Plan 1 is better than Plan 2, Plan 2 is better than Original Plan, Plan 4 is better than Original Plan, Plan 4 is better than Plan1, Plan 4 is better than Plan 2, hence one can say that Plan 4 is the best amongst all the proposed plan.

\section{Conclusions}

The research was to understand the importance of healthcare facility planning and how it can impact all the major and minor decision within the facility. A survey questionnaire was developed and utilised to understand it from all the major stakeholders' perspective. Considering an existing facility, the research utilises a combined approach to improve the existing layout by understanding the

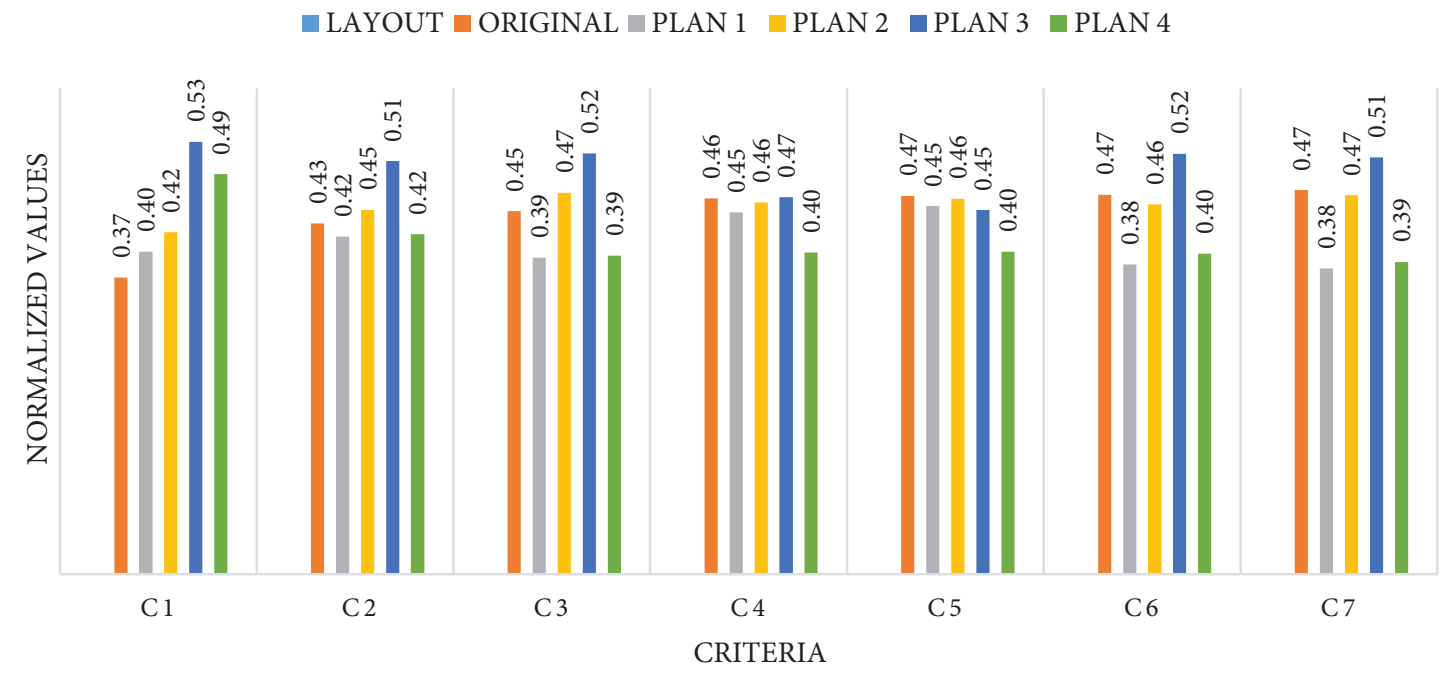

Figure 11. Bar chart for criteria comparison of the layouts 
experience and problems of its stakeholders. This study optimizes several quantitative criteria related to economics, technology and society which are taken into consideration for the decision-making during the evaluation, analysis, and selection of the best layout for an existing healthcare facility.

Critical areas for the improvement were identified using statistical analysis based on the survey and Apple's layout procedure is used to design the different possible layouts for an efficient facility. The seven criteria namely inter-departmental satisfactory level, the average distance travelled and the average time required for staff flow, the average distance travelled and the average time required for patient flow, the average distance travelled and the average time required for material flow were taken into consideration. The ELECTRE methodology was used as multi-criteria decision making based on seven criteria for comparing the different layout by methodical and orderly thinking. With the growing healthcare sector in India as well as around the globe, this research extends the knowledge by providing the practical methods to optimise operations of the healthcare facilities. This would further enhance the efficiency and effectiveness of crucial services provided by the respective healthcare sector and increase customer satisfaction.

This research has its limitations as it has not incorporated factors such as funding, indoor climate, temperature, humidity, and light. Future research is highly recommended to incorporate these criteria. Further studies can also be done on how partial automation strategies can be implemented to increase the efficiency and effectiveness of the optimized layout, by optimizing the data flow and analysis within the facility for better decision making. Further research for comparison analysis can be conducted with other MCDM methods as well as previously published scholarly research.

\section{Author contributions}

Vimal K.E.K: ideas, conceptualization, writing-original draft preparation, data collation and curation, methodology. Jayakrishna Kandasamy: conceptualization, writingoriginal draft preparation, data collation and curation, methodology. Simon Peter Nadeem: writing, reviewing and editing (critical review, commentary and revision). Anil Kumar: formal analysis, conceptualization, project administration and revision. Jonas Šaparauskas: reviewing idea, conceptualization, supervision, project administration. Jose Arturo Garza-Reyes: conceptualization, interpretation, supervision, project administration. Eva Trinkūnienè: conceptualization, interpretation, supervision, project administration.

\section{Disclosure statement}

The authors have no known competing financial interests or personal relationships that could have appeared to influence the work reported in this paper.

\section{References}

Agrebi, M., Abed, M., \& Omri, M. N. (2017). ELECTRE I based relevance decision-makers feedback to the location selection of distribution centers. Journal of Advanced Transportation, 1, 1-10. https://doi.org/10.1155/2017/7131094

Ahmadi, A., Pishvaee, M. S., \& Jokar, M. R. A. (2017). A survey on multi-floor facility layout problems. Computers \& Industrial Engineering, 107, 158-170.

https://doi.org/10.1016/j.cie.2017.03.015

Aiello, G., \& Galante, M. E. G. (2006). A multi-objective approach to facility layout problem by genetic search algorithm and Electre method. Robotics and Computer-Integrated Manufacturing, 22(5-6), 447-455.

https://doi.org/10.1016/j.rcim.2005.11.002

Amankwah, O., Choong, W.-W., \& Mohammed, A. H. (2019). Modelling the influence of healthcare facilities management service quality on patients satisfaction. Journal of Facilities Management, 17(3), 267-283. https://doi.org/10.1108/JFM-08-2018-0053

Amine, D., Pierreval, H., \& Hajri-Gabouj, S. (2007). Facility layout problems: a survey. Annual Reviews in Control, 31, 255267. https://doi.org/10.1016/j.arcontrol.2007.04.001

Beccali, M., Cellura, M., \& Mistretta, M. (2003). Decision-making in energy planning. Application of the Electre method at regional level for the diffusion of renewable energy technology. Renewable Energy, 28(13), 2063-2087.

https://doi.org/10.1016/S0960-1481(03)00102-2

Benitez, G. B., Da Silveira, G. J., \& Fogliatto, F. S. (2019). Layout planning in healthcare facilities: a systematic review. HERD: Health Environments Research \& Design Journal, 12(3), 31-44. https://doi.org/10.1177/1937586719855336

Bozer, Y. A., Meller, R. D., \& Erlebacher, S. J. (1994). An improvement-type layout algorithm for single and multiplefloor facilities. Management Science, 40(7), 918-932.

https://doi.org/10.1287/mnsc.40.7.918

Che-Ani, A. I., \& Ali, R. (2019). Facility management demand theory. Journal of Facilities Management, 17(4), 344-355. https://doi.org/10.1108/JFM-09-2018-0057

Chen, C. W., \& Sha, D. Y. (2001). A literature review and analysis to the facility layout problem. Journal of the Chinese Institute of Industrial Engineers, 18(1), 55-73. https://doi.org/10.1080/10170660109509447

de Almeida, A. T. (2007). Multicriteria decision model for outsourcing contracts selection based on utility function and ELECTRE method. Computers \& Operations Research, 34(12), 3569-3574. https://doi.org/10.1016/j.cor.2006.01.003

Doulabi, R. Z., \& Asnaashari, E. (2016). Identifying success factors of healthcare facility construction projects in Iran. Procedia Engineering, 164, 409-415.

https://doi.org/10.1016/j.proeng.2016.11.638

Dwijayanti, K., Dawal, S. Z. M., \& Aoyama, H. (2010). A proposed study on facility planning and design in manufacturing process. In International MultiConference of Engineers and Computer Scientists 2010, IMECS 2010 (pp. 1640-1645). Kowloon, Hong Kong.

Fei, L., Xia, J., Feng, Y., \& Liu, L. (2019). An ELECTRE-based multiple criteria decision making method for supplier selection using Dempster-Shafer theory. IEEE Access, 7, 8470184716. https://doi.org/10.1109/ACCESS.2019.2924945

Girubha, J., Vinodh, S., \& Kek, V. (2016). Application of interpretative structural modelling integrated multi criteria decision making methods for sustainable supplier selection. Journal of Modelling in Management, 11(2), 358-388. https://doi.org/10.1108/JM2-02-2014-0012 
Gonzalez, M. E. (2019). Improving customer satisfaction of a healthcare facility: reading the customers' needs. Benchmarking: An International Journal, 26(3), 854-870.

https://doi.org/10.1108/BIJ-01-2017-0007

Helber, S., Böhme, D., Oucherif, F., Lagershausen, S., \& Kasper, S. (2016). A hierarchical facility layout planning approach for large and complex hospitals. Flexible Services and Manufacturing Journal, 28(1-2), 5-29. https://doi.org/10.1007/s10696-015-9214-6

Heragu, S. S. (2016). Facilities design (4th ed.). CRC Press.

Holden, R. J. (2009). People or systems? To blame is human. The fix is to engineer. Professional Safety, 54(12), 34.

IBEF Report. (2020). Healthcare industry in India. https://www. ibef.org/industry/healthcare-india.aspx

Joseph, A., \& Rashid, M. (2007). The architecture of safety: hospital design. Current Opinion in Critical Care, 13(6), 714-719. https://doi.org/10.1097/MCC.0b013e3282f1be6e

Komarudin, \& Wong, K. Y. (2010). Applying ant system for solving unequal area facility layout problems. European Journal of Operational Research, 202(3), 730-746.

https://doi.org/10.1016/j.ejor.2009.06.016

Krupka, D. C., \& Sandberg, W. S. (2006). Operating room design and its impact on operating room economics. Current Opinion in Anesthesiology, 19(2), 185-191.

https://doi.org/10.1097/01.aco.0000192795.64678.e7

Łaska, G. (2017). Wind energy and multi-criteria analysis in making decisions on the location of wind farms. Procedia Engineering, 182, 418-424.

https://doi.org/10.1016/j.proeng.2017.03.126

Lather, J. I., Logan, T., Renner, K., \& Messner, J. I. (2020). Implementation and evaluation of generative layout options using the graph theoretical approach for a hospital layout problem. Journal of Computing in Civil Engineering, 34(4), 04020014. https://doi.org/10.1061/(ASCE)CP.1943-5487.0000893

Liu, J., \& Liu, J. (2019). Applying multi-objective ant colony optimization algorithm for solving the unequal area facility layout problems. Applied Soft Computing, 74, 167-189. https://doi.org/10.1016/j.asoc.2018.10.012

Mary, S. S. A., \& Suganya, G. (2016). Multi-criteria decision making using ELECTRE. Circuits and Systems, 7(6), 10081020. https://doi.org/10.4236/cs.2016.76085

Meller, R. D., \& Bozer, Y. A. (1997). Alternative approaches to solve the multi-floor facility layout problem. Journal of Manufacturing Systems, 16(3), 192-203.

https://doi.org/10.1016/S0278-6125(97)88887-5

Meller, R. D., \& Gau, K. Y. (1996). The facility layout problem: recent and emerging trends and perspectives. Journal of Manufacturing Systems, 15(5), 351-366.

https://doi.org/10.1016/0278-6125(96)84198-7

Mills, G. R., Deka, L., Price, A. D., Rich-Mahadkar, S., Pantzartzis, E., \& Sellars, P. (2015). Critical infrastructure risk in NHS England: predicting the impact of building portfolio age. International Journal of Strategic Property Management, 19(2), 159-172. https://doi.org/10.3846/1648715X.2015.1029562

Mishra, A. R., Singh, R. K., \& Motwani, D. (2020). Intuitionistic fuzzy divergence measure-based ELECTRE method for performance of cellular mobile telephone service providers. Neural Computing and Applications, 32(8), 3901-3921. https://doi.org/10.1007/s00521-018-3716-6

Palatnik, A. M. (2016). To err IS human. Nursing Critical Care, 11(5), 4. https://doi.org/10.1097/01.CCN.0000490961.44977.8d

Palmer, G., Abernathy, J. H., Swinton, G., Allison, D., Greenstein, J., Shappell, S., Juang, K., \& Reeves, S. T. (2013). Realizing improved patient care through human-centered operating room design a human factors methodology for observing flow disruptions in the cardiothoracic operating room. The Journal of the American Society of Anesthesiologists, 119(5), 1066-1077. https://doi.org/10.1097/ALN.0b013e31829f68cf

Prugsiganont, S., \& Jensen, P. A. (2019). Identification of space management problems in public hospitals: the case of Maharaj Chiang Mai Hospital. Facilities, 37(7/8), 435-454. https://doi.org/10.1108/F-01-2018-0001

Reason, J. (2000). Human error: models and management. BMJ, 320(7237), 768-770.

https://doi.org/10.1136/bmj.320.7237.768

Reijula, J., Reijula, E., \& Reijula, K. (2016). Insight into healthcare design: lessons learned in two university hospitals. Journal of Facilities Management, 14(3), 266-282.

https://doi.org/10.1108/JFM-01-2016-0001

Riedel, R. (2011). Facilities planning - 4th edition by J.A. Tompkins, J.A. White, Y.A. Bozer and J.M.A. Tanchoco. International Journal of Production Research, 49(24), 7519-7520. https://doi.org/10.1080/00207543.2011.563164

Roy, B. (1991). The outranking foundations approach and the methods. Theory and Decision, 31, 49-73.

https://doi.org/10.1007/BF00134132

Salminen, P., Hokkanen, J., \& Lahdelma, R. (1998). Comparing multicriteria methods in the context of environmental problems. European Journal of Operational Research, 104(3), 485-496. https://doi.org/10.1016/S0377-2217(96)00370-0

Schaumann, D., Putievsky Pilosof, N., Gath-Morad, M., \& Kalay, Y. E. (2020). Simulating the impact of facility design on operations: a study in an internal medicine ward. Facilities, 38(7/8), 501-522. https://doi.org/10.1108/F-10-2018-0132

Sevkli, M. (2010). An application of the fuzzy ELECTRE method for supplier selection. International Journal of Production Research, 48(12), 3393-3405.

https://doi.org/10.1080/00207540902814355

Shariff, S. R., Moin, N. H., \& Omar, M. (2012). Location allocation modeling for healthcare facility planning in Malaysia. Computers \& Industrial Engineering, 62(4), 1000-1010. https://doi.org/10.1016/j.cie.2011.12.026

Shohet, I. M., \& Lavy, S. (2017). Facility maintenance and management: a health care case study. International Journal of Strategic Property Management, 21(2), 170-182. https://doi.org/10.3846/1648715X.2016.1258374

Shojaie, A. A., Babaie, S., Sayah, E., \& Mohammaditabar, D. (2018). Analysis and prioritization of green health suppliers using Fuzzy ELECTRE method with a case study. Global Journal of Flexible Systems Management, 19(1), 39-52. https://doi.org/10.1007/s40171-017-0168-2

Tongur, V., Hacibeyoglu, M., \& Ulker, E. (2019). Solving a bigscaled hospital facility layout problem with meta-heuristics algorithms. Engineering Science and Technology, an International Journal, 23(4), 951-959. https://doi.org/10.1016/j.jestch.2019.10.006

Ulubeyli, S., \& Kazaz, A. (2009). A multiple criteria decisionmaking approach to the selection of concrete pumps. Journal of Civil Engineering and Management, 15(4), 369-376. https://doi.org/10.3846/1392-3730.2009.15.369-376

Wanigarathna, N., Jones, K., Bell, A., \& Kapogiannis, G. (2019). Building information modelling to support maintenance management of healthcare built assets. Facilities, 37(7/8), 415-434. https://doi.org/10.1108/F-01-2018-0012

Young, J. M., Tietz, C., \& Panagiotopoulos, A. Z. (2019). Activity coefficients and solubility of $\mathrm{CaCl}_{2}$ from molecular simulations. Journal of Chemical \& Engineering Data, 65(2), 337348. https://doi.org/10.1021/acs.jced.9b00688

Yousefli, Z., Nasiri, F., \& Moselhi, O. (2017), Healthcare facilities maintenance management: a literature review. Journal of Facilities Management, 15(4), 352-375. https://doi.org/10.1108/JFM-10-2016-0040 


\section{Appendix}

Appendix 1. Department names and their annotation

\begin{tabular}{|c|c|}
\hline Name of department & Annotation \\
\hline Reception & W1 \\
\hline Consultation room $2,4,5$ & $\mathrm{~A}$ \\
\hline Consultation room $3+$ Managing & $\mathrm{B}$ \\
\hline Waiting 2 & W2 \\
\hline Kids room & $\mathrm{C}$ \\
\hline Waiting 3 & W3 \\
\hline Consultation room 6 & $\mathrm{D}$ \\
\hline Minor OT & $\mathrm{E}$ \\
\hline Physiotherapy & $\mathrm{F}$ \\
\hline X-Ray & G \\
\hline IP & $\mathrm{H}$ \\
\hline Pharmacy & I \\
\hline Canteen & $\mathrm{J}$ \\
\hline Waiting 4 & W4 \\
\hline Consultation room $13,14,15+$ Toilet & $\mathrm{K}$ \\
\hline EMR + Toilet & $\mathrm{L}$ \\
\hline Lab & $\mathrm{M}$ \\
\hline OT & $\mathrm{O}$ \\
\hline Semi private ward & $\mathrm{P}$ \\
\hline $\mathrm{M} / \mathrm{F}$ staff room & Q \\
\hline Private ward AC & $\mathrm{R}$ \\
\hline $\mathrm{HDU}$ & $\mathrm{T}$ \\
\hline Storage & $S$ \\
\hline Nursing point & $\mathrm{N}$ \\
\hline Private ward non-AC & $\mathrm{U}$ \\
\hline Dental (DR) & $\mathrm{V}$ \\
\hline Scan room & W \\
\hline Labour room & $\mathrm{X}$ \\
\hline MRD & $\mathrm{Y}$ \\
\hline Canteen & $\mathrm{Z}$ \\
\hline $\mathrm{MGW}+\mathrm{FGW}+\mathrm{PGW}$ & a \\
\hline Endoscopy & $\mathrm{b}$ \\
\hline $\mathrm{ICU}+\mathrm{NICU}$ & c \\
\hline Housekeeping & $\mathrm{d}$ \\
\hline Pharmacy purchase $+\mathrm{HR}+$ maintenance & e \\
\hline
\end{tabular}

Appendix 2. The calculation for average distance from pharmacy towards for current layout

\begin{tabular}{|c|c|c|c|c|c|c|c|}
\hline & 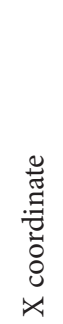 & 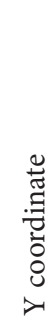 & 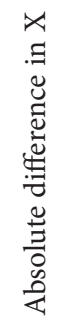 & 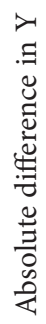 & 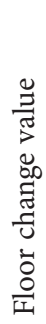 & $\underset{0}{\overrightarrow{0}}$ & 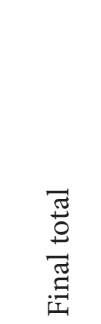 \\
\hline Pharmacy & 37.5 & 129 & - & - & - & - & - \\
\hline Stairs & 32 & 86 & 5.5 & 43 & - & 48.5 & 48.5 \\
\hline Semi private ward & 8.5 & 61 & 23.5 & 25 & 20 & 68.5 & - \\
\hline Private ward AC & 19 & 18 & 13 & 68 & 20 & 101 & - \\
\hline Private ward non-AC & 51 & 50 & 19 & 36 & 20 & 75 & - \\
\hline General ward & 16 & 36 & 16 & 50 & 40 & 106 & - \\
\hline \multicolumn{6}{|c|}{ Average distance to wards } & 87.6 & 87.6 \\
\hline \multicolumn{7}{|c|}{ Total distance travelled from pharmacy to wards } & 136.125 \\
\hline
\end{tabular}

Appendix 3. Calculation of average distance for material flow in the current layout

\begin{tabular}{|c|c|c|c|c|c|c|c|c|}
\hline $\begin{array}{l}\tilde{U} \\
\tilde{w}\end{array}$ & 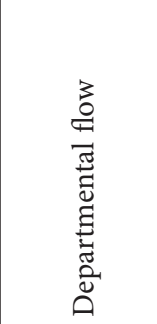 & 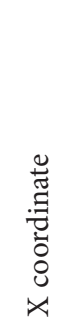 & 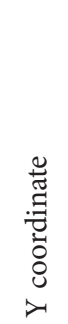 & 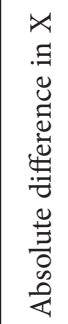 & 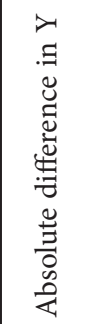 & 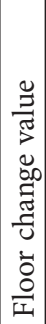 & 퓽 & 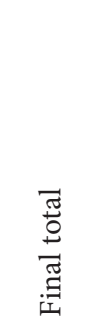 \\
\hline \multirow{2}{*}{$\begin{array}{l}\text { EMR } \\
\text { case }\end{array}$} & Pharmacy & 37.5 & 129 & - & - & - & - & \multirow[t]{2}{*}{88.5} \\
\hline & EMR & 42 & 45 & 4.5 & 84 & - & 88.5 & \\
\hline \multirow{3}{*}{$\begin{array}{l}\text { Fever } \\
\text { case }\end{array}$} & Pharmacy & 37.5 & 129 & - & - & - & - & \multirow[t]{3}{*}{135.5} \\
\hline & Reception & 17 & 24.5 & 20.5 & 104.5 & - & 125 & \\
\hline & $\begin{array}{l}\text { Main gate / } \\
\text { Exit }\end{array}$ & 17 & 14 & 0 & 10.5 & - & 10.5 & \\
\hline \multirow{2}{*}{$\begin{array}{l}\text { IP } \\
\text { case }\end{array}$} & Pharmacy & 37.5 & 129 & - & - & - & - & \multirow[t]{2}{*}{136.1} \\
\hline & Wards & - & - & - & - & - & 136.125 & \\
\hline \multicolumn{8}{|c|}{ Total distance travelled for material flow } & 360.1 \\
\hline \multicolumn{8}{|c|}{ Average distance travelled for material flow } & 120.04 \\
\hline
\end{tabular}


Appendix 4. Calculation of the average distance for staff flow in the current layout

\begin{tabular}{|c|c|c|c|c|c|c|c|c|}
\hline Cases & Departmental flow & 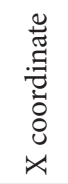 & 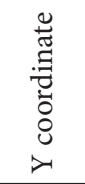 & 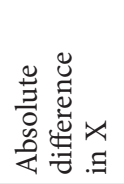 & 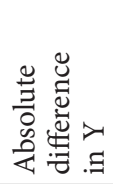 & 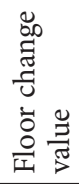 & تี & 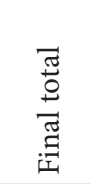 \\
\hline \multirow[t]{7}{*}{ EMR Case } & EMR & 42 & 45 & - & - & - & - & \multirow[t]{7}{*}{487.6} \\
\hline & Minor OT & 7 & 118.5 & 35 & 73.5 & - & 108.5 & \\
\hline & Stairs & 32 & 86 & 25 & 32.5 & - & 57.5 & \\
\hline & OT & 16 & 115 & 16 & 29 & 20 & 65 & \\
\hline & Stairs & 32 & 86 & 16 & 29 & - & 45 & \\
\hline & ICU & 16 & 127 & 16 & 41 & 20 & 77 & \\
\hline & Wards & - & - & - & - & - & 134.6 & \\
\hline \multirow[t]{6}{*}{ Severe illness } & Nursing & - & - & - & - & - & - & \multirow[t]{6}{*}{580.3} \\
\hline & Wards & - & - & - & - & - & 138.1 & \\
\hline & OT & - & - & - & - & - & 112.6 & \\
\hline & Stairs & 32 & 86 & 32 & 86 & - & 118 & \\
\hline & ICU & 16 & 127 & 16 & 41 & 20 & 77 & \\
\hline & Wards & - & - & - & - & - & 134.6 & \\
\hline \multirow[t]{6}{*}{ General flow } & Private ward & 51 & 50 & - & - & - & - & \multirow[t]{6}{*}{344.5} \\
\hline & Semi Private ward & 8.5 & 61 & 42.5 & 11 & - & 53.5 & \\
\hline & Stairs & 32 & 86 & 23.5 & 25 & - & 48.5 & \\
\hline & General ward & 16 & 36 & 16 & 50 & 20 & 86 & \\
\hline & Stairs & 32 & 86 & 16 & 50 & - & 66 & \\
\hline & Nursing centre & 39.5 & 23 & 7.5 & 63 & 20 & 90.5 & \\
\hline \multicolumn{8}{|c|}{ Total distance travelled for staff flow } & 1412.4 \\
\hline \multicolumn{8}{|c|}{ Average distance travelled for staff flow } & 470.8 \\
\hline
\end{tabular}

Appendix 5. The calculation for the average distance for patient flow in the current layout

\begin{tabular}{|c|c|c|c|c|c|c|c|c|}
\hline Cases & Departmental flow & 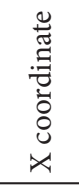 & 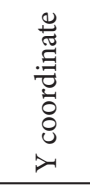 & 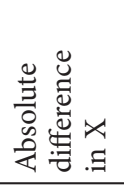 & 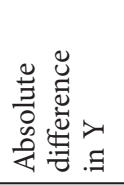 & 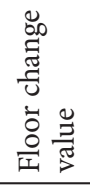 & 胥 & 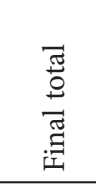 \\
\hline \multirow[t]{5}{*}{ EMR case } & Back door / Entry & 64 & 159 & - & - & - & - & \multirow[t]{5}{*}{418.6} \\
\hline & EMR & 42 & 45 & 22 & 114 & - & 136 & \\
\hline & Stairs & 32 & 86 & 10 & 41 & - & 51 & \\
\hline & ICU & 16 & 127 & 16 & 41 & 40 & 97 & \\
\hline & Wards & - & - & - & - & - & 134.6 & \\
\hline \multirow{4}{*}{$\begin{array}{l}\text { Severe illness } \\
\text { case }\end{array}$} & Reception & 17 & 24.5 & - & - & - & - & \multirow[t]{4}{*}{249.1} \\
\hline & Consulting room & 7 & 51.5 & 10 & 27 & - & 37 & \\
\hline & MOT & 7 & 118.5 & 0 & 67 & - & 67 & \\
\hline & Wards & - & - & - & - & - & 145.1 & \\
\hline \multirow[t]{4}{*}{ Fever case } & Reception & 17 & 24.5 & - & - & - & - & \multirow[t]{4}{*}{270} \\
\hline & Consulting room & 7 & 51.5 & 10 & 27 & - & 37 & \\
\hline & Pharmacy & 37.5 & 129 & 30.5 & 77.5 & - & 108 & \\
\hline & Reception (Billing) & 17 & 24.5 & 20.5 & 104.5 & - & 125 & \\
\hline \multirow[t]{4}{*}{ Diagnostics case } & Reception & 17 & 24.5 & - & - & - & & \multirow[t]{4}{*}{217} \\
\hline & Consulting room & 7 & 51.5 & 10 & 27 & - & 37 & \\
\hline & Physiotherapy & 22 & 126.5 & 15 & 75 & - & 90 & \\
\hline & Consulting room & 7 & 51.5 & 15 & 75 & - & 90 & \\
\hline \multirow[t]{4}{*}{ Internal injuries } & Reception & 17 & 24.5 & - & - & - & & \multirow[t]{4}{*}{185} \\
\hline & Consulting room & 7 & 51.5 & 10 & 27 & - & 37 & \\
\hline & X-Ray & 25 & 107.5 & 18 & 56 & - & 74 & \\
\hline & Consulting room & 7 & 51.5 & 18 & 56 & - & 74 & \\
\hline \multicolumn{8}{|c|}{ Total distance travelled for patient flow } & 1339.7 \\
\hline \multicolumn{8}{|c|}{ Average distance travelled for staff flow } & 267.94 \\
\hline
\end{tabular}


Appendix 6. Assumed values of speed for time matrix calculation

\begin{tabular}{|l|c|c|}
\hline \multicolumn{1}{|c|}{ Type of flow } & Type of case & Speed (ft / sec) \\
\hline Materials flow & EMR & 4 \\
\cline { 2 - 3 } & Fever & 2 \\
\cline { 2 - 3 } & IP & 3 \\
\hline Staff flow & EMR & 4 \\
\cline { 2 - 3 } & Severe illness & 3 \\
\cline { 2 - 3 } & General & 2 \\
\hline Patients flow & EMR & 5 \\
\cline { 2 - 3 } & Severe illness & 3 \\
\cline { 2 - 3 } & Fever & 2 \\
\cline { 2 - 3 } & Diagnostics & 2 \\
\cline { 2 - 3 } & Internal injuries & 3 \\
\hline
\end{tabular}

Appendix 7. Overall time matrix

\begin{tabular}{|c|c|c|c|c|c|c|c|c|c|c|c|}
\hline & \multicolumn{3}{|c|}{ Materials flow } & \multicolumn{3}{|c|}{ Staff flow } & \multicolumn{5}{|c|}{ Patients flow } \\
\hline & $\sum_{i=1}^{\mathfrak{1}}$ & $\begin{array}{l}\bar{\Delta} \\
\vec{u} \\
\end{array}$ & 目 & $\sum_{i=1}^{\mathfrak{1}}$ & 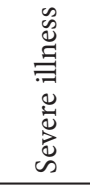 & 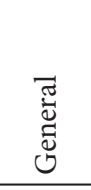 & $\sum_{\text {I }}^{\mathscr{1}}$ & 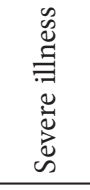 & $\vec{D}_{\bar{U}}^{\vec{D}}$ & 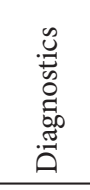 & 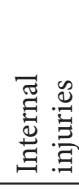 \\
\hline Current & 22.1 & 67.8 & 45.4 & 121.9 & 193.5 & 172.3 & 83.7 & 83.0 & 135.0 & 108.5 & 61.7 \\
\hline Plan 1 & 28.0 & 35.0 & 54.9 & 108.7 & 193.5 & 172.3 & 67.3 & 79.9 & 60.5 & 107.3 & 60.8 \\
\hline Plan 2 & 20.6 & 72.8 & 48.7 & 117.9 & 193.5 & 172.3 & 77.3 & 81.9 & 139.5 & 106.8 & 60.5 \\
\hline Plan 3 & 22.1 & 67.8 & 66.8 & 130.7 & 215.8 & 122.8 & 96.0 & 111.0 & 135.0 & 108.5 & 61.7 \\
\hline Plan 4 & 28.0 & 35.0 & 55.7 & 111.1 & 155.0 & 149.3 & 74.5 & 80.7 & 60.5 & 107.3 & 60.8 \\
\hline
\end{tabular}

Appendix 8. Relationship score between departments for the ground floor of the current layout

\begin{tabular}{|c|c|c|c|c|}
\hline & \multicolumn{2}{|c|}{ Departments } & Relation & Score \\
\hline \multirow[t]{20}{*}{ Same floor } & $\mathrm{A}$ & W1 & A & 4 \\
\hline & $\mathrm{A}$ & W3 & $\mathrm{A}$ & 4 \\
\hline & B & W1 & $\mathrm{A}$ & 4 \\
\hline & $\mathrm{B}$ & W2 & $\mathrm{A}$ & 4 \\
\hline & $\mathrm{B}$ & $\mathrm{L}$ & E & 3 \\
\hline & $\mathrm{C}$ & W2 & $\mathrm{X}$ & -4 \\
\hline & $\mathrm{C}$ & $\mathrm{L}$ & I & 2 \\
\hline & $\mathrm{D}$ & W3 & $\mathrm{A}$ & 4 \\
\hline & $\mathrm{D}$ & $\mathrm{E}$ & $\mathrm{O}$ & 1 \\
\hline & $\mathrm{E}$ & $\mathrm{F}$ & I & 2 \\
\hline & $\mathrm{F}$ & $\mathrm{G}$ & $\mathrm{A}$ & 4 \\
\hline & $G$ & $\mathrm{H}$ & $\mathrm{X}$ & -4 \\
\hline & $\mathrm{G}$ & I & $\mathrm{U}$ & 0 \\
\hline & $\mathrm{H}$ & I & $\mathrm{A}$ & 4 \\
\hline & $\mathrm{H}$ & W4 & $\mathrm{E}$ & 3 \\
\hline & I & $J$ & $\mathrm{U}$ & 0 \\
\hline & I & W4 & $\mathrm{A}$ & 4 \\
\hline & $\mathrm{J}$ & W4 & $\mathrm{O}$ & 1 \\
\hline & $\mathrm{K}$ & $\mathrm{L}$ & $\mathrm{E}$ & 3 \\
\hline & $\mathrm{L}$ & $\mathrm{M}$ & I & 2 \\
\hline
\end{tabular}

\begin{tabular}{|l|c|c|c|c|}
\hline \multirow{3}{*}{ Floor change } & \multicolumn{2}{|c|}{ Departments } & Relation & Score \\
\cline { 2 - 5 } & $\mathrm{C}$ & $\mathrm{T}$ & $\mathrm{X}$ & -4 \\
\cline { 2 - 5 } & $\mathrm{C}$ & $\mathrm{O}$ & $\mathrm{U}$ & 0 \\
\cline { 2 - 5 } & $\mathrm{C}$ & $\mathrm{W}$ & $\mathrm{I}$ & 2 \\
\cline { 2 - 5 } & $\mathrm{C}$ & $\mathrm{U}$ & $\mathrm{U}$ & 0 \\
\cline { 2 - 5 } & $\mathrm{G}$ & $\mathrm{W}$ & $\mathrm{U}$ & 0 \\
\cline { 2 - 5 } & $\mathrm{G}$ & $\mathrm{Z}$ & $\mathrm{X}$ & -4 \\
\cline { 2 - 5 } & $\mathrm{H}$ & $\mathrm{Z}$ & $\mathrm{U}$ & 0 \\
\cline { 2 - 5 } & $\mathrm{H}$ & $\mathrm{W}$ & $\mathrm{I}$ & 2 \\
\hline Total REL score & \multicolumn{3}{|l}{} & 37 \\
\hline
\end{tabular}

